\title{
IAMJ
}

INTERNATIONAL

AYURVEDIC

MEDICAL JOURNAL

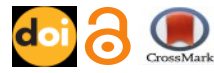

Review Article

ISSN: 2320-5091

Impact Factor: 6.719

\section{STEP TOWARDS UNDERSTANDING THE MYSTERY OF MENIERE'S DISEASE THROUGH AYURVEDA}

\author{
Anuradha Biserotti ${ }^{1}$, Prashanth A. $\mathbf{S}^{2}$ \\ ${ }^{1}$ Second Year PG Scholar, Dept of Kayachikitsa \\ ${ }^{2}$ Professor \& HOD Kayachikitsa Ayurveda Mahavidyalaya, Hubli, Karnataka, India
}

Corresponding Author: anubiserotti@gmail.com

\section{https://doi.org/10.46607/iamj13p5022021}

(Published online: January 2021)

Open Access

(C) International Ayurvedic Medical Journal, India 2021

Article Received: 10/02/2021 - Peer Reviewed: 11/02/2021 - Accepted for Publication: 12/02/2021

Check for updates

\section{ABSTRACT}

Meniere's disease is an inner ear disease characterised by episodes of Vertigo, fluctuating sensorineural hearing loss and Tinnitus, associated with Aural pressure Drop attacks (falls without loss of consciousness), Nystagmus, Headache and Nausea. Relapsing nature of the disease hampers the quality of life in patients. And also affects the psychosocial status of the patient. The main pathology occurs as the result of endolymphatic system distension, caused by the excessive accumulation of endolymph. This can result from excessive production or reduced absorption of endolymph or both. By knowing the pathology of the Meniere's disease, clinical features and signs we can consider Karna Nada, Karna Kshweda, (Tinnitus) Badhirya (Hearing Loss) and Bhrama (vertigo) into consideration in which we encounter the vitiation of Karnagata Tarpaka Kapha and Vata. Hence treatment should be aimed at Agni deepana, Vata Anulomana, Vata Kapha Shamana. Nasya Karma, Karna Poorana, Shamana Snehapana, Snigdha Virechana can be employed in the management of Meniere's Disease.

Keywords: Meniere's disease, Karna nada, Karna kshweda, Badhirya

\section{INTRODUCTION}

Meniere's disease is a disorder of the inner ear characterised by Vertigo, Tinnitus, Fluctuating hearing loss and Aural pressure. It was first described by Prosper Meniere in 1861. The etiology and pathogenesis of the disease remain elusive. However environmental and genetic factors can be considered. It can be seen in almost all ages. Peak incidence in $4^{\text {th }}$ to $6^{\text {th }}$ decade of life. 
It is considered one among national rare disorder of India. The worldwide incidence of Meniere's disease is approximately 12 out of every 1,000 people. Perhaps 100,000 patients develop Meniere's disease every year'.

Shravanendriya is Sukshma, Vivara Yukta and Avakasha Yukta Indriya. Shravanendriya is the seat of Vata mainly Praana, Udaana, Vyana Vata; and Kapha that is Tarpaka Kapha; which nourishes the Shravanendriya. The normalcy of all the three Doshas maintains the karma of Shravanendriya. The vitiation of the Doshas leads to Karna Rogas (ear diseases) and improper functioning of Karnendriya.

\section{Aetiology and Pathogenesis of Meniere's:}

Etiology: ${ }^{2}$

The exact causes are unknown, but the various theories are postulated

- Defective absorption of Endolymph:

Ischemia of Sac

Vasomotor Disturbances: Sympathetic over activity leading to spasm of internal auditory artery

- Increased production of Endolymph

Allergy: Inner ear acts as a 'shock organ' producing excess of endolymph

Sodium and water retention

- Hypothyroidism

- Auto immune etiology

- Viral etiology

The main pathology believed to occur as because of the distension of endolymphatic sac (endolymph hydrops) resulted from excessive production of endolymph or faulty absorption of endolymph or both. Under normal conditions most endolymph production and absorption occur in the organ of corti utricle saccule and semi-circular canals.

Various theories are postulated regarding the excessive production and defective absorption of endolymph. There will be dilatation in the cochlear duct, saccule, utricle. The reissener's membrane bulges into scala vestibuli. Herniation and rupture of reissener's membrane leads to leakage of $\mathrm{k}+$ rich endolymph into perilymphatic space causing vestibulocochlear nerve depolarisation causing reduced neuronal outflow. The trig- gering factors of the Meniere's disease are psychological disorders, stress, improper daily regime, excessive exposure to loud sounds, excessive travelling, prolonged usage of ac facility. ${ }^{3,4,5}$

By seeing the Meniere's disease pathophysiology and clinical symptoms and signs we can probably take into considerations of Ayurvedic entities like Karna Kshweda, Karna nada (Tinnitus), Bhrama (Vertigo), Badhirya (Hearing Loss) in which the vitiation of Karnagata Tarpaka Kapha and Vata is seen. Exposure to cold breeze, intake of cold, unctuous food, Noise pollution (Mithya yoga of Shabda i.e. continuous exposure to high pitch sounds like in some factories, traffic), improper sleep pattern (Ratrijagarana), swimming, excessive travelling, Karnakadooyana, Pratishyaya, Excessive usage of headphones, untreated chronic Systemic illness.

Due to these Nidana sevana; Prakopa of Vata in Urdhwa Gami Siras of Shravanendriya which will disrupt the normal Karma of Shravanendriya. Tarpaka kapha in Karna gets aggravated due to some Nidanas like Abhishyandi Ahara Sevana, swimming which causes Margavarodha hence the Vata gets vitiated and aggravated and in later stages the aggravated Vata dries up the nourishing Tarpaka Kapha and manifests into different Lakshanas like Karna nada, Karna kshweda, Badhirya, Bhrama.

The aggravated Vata Dosha either entering into other channels or encircled by Kapha Dosha in Shabdavaha Srotas produces different types of sounds like Bheri, Mrudanga, Shanka etc. in the ears is Karna nada ${ }^{6}$ (tinnitus).

And in Karnakshweda vitiation of three Doshas Venu Ghoshavat sound is heard in ears. These both conditions are explained by Acharya Sushruta can be considered as Tinnitus. In Badhirya ${ }^{7}$ due to various etiological factors vitiation of Vata and Kapha, Vata is being obstructed or hindered by Kapha, because of the obstruction in the Gati of Vata its activities will be hampered, which results in the improper conduction of sound. Badhirya can be Dhatu kshaya janya (Kevala Vata Janya) and Kaphavrita Vata Janya also.

Acharya Vagbhata quotes that if we don't treat Karna naada it may lead to Badhirya. Due to untreated 
chronic illnesses like otitis media, Karna Paka (Inflammatory condition of Ear), Puya Srava (pus discharge). Vata Dosha in association with Laghu Guna Vruddhi of pitta causes Laghavata light headedness/dizziness. The Sthanika Kapha Dushti in Karna produces Guruta that is ear fullness. Acharya Sushruta opines that the involvement of Rajas, Pitta and Vata Dosha produces Bhrama $^{8}$. Madhavakara explains about Bhrama as Chakravat Bhramate here patient experiences spinning movements in the head and patient loses his balance; and keeps falling repeatedly ${ }^{8}$. Bhrama is a Rasa Dhatu Kshya Lakshana and one among Vataja Nanatmaja Vikara. The Samprapti of Meniere's can be understood as of Margavarana Janya and Dhatukshyajanya. The main pathology is defective absorption of endolymph and excessive production is because of Margavarana caused by Dosha and causing the distention of membranous labyrinth, utricle saccule. And chronic Margavarana leads to Dhatukshaya and causes degenerative changes in vestibulocochlear nerve.

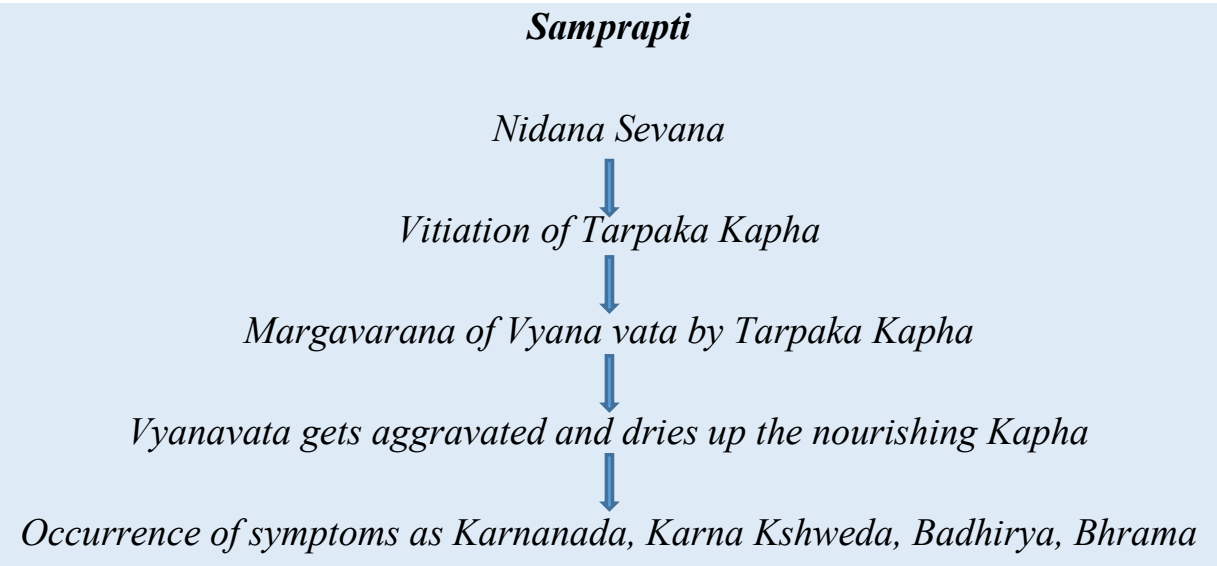

Diagnosis: Diagnostic criteria as of 2015 by ICVD [International Classification of Vestibular Disorders] is included ${ }^{9}$

\section{Definite Meniere's disease}

1. Two or more episodes of vertigo each lasting 20 minutes to 12 hours.

2. Audiometrically documented low to medium frequency sensorineural hearing loss in the affected ear on at least 1 occasion before, during or after one of the episodes of vertigo.

3. Fluctuating aural symptoms in the affected ear.

4. Not better accounted for by another vestibular diagnosis

Probable Meniere's disease

1. Two or more episodes of vertigo or dizziness each lasting 20 minutes to 24 hours.

2. Fluctuating aural symptoms in the reported ear.

3. Not better accounted for by another vestibular diagnosis.

\section{Investigations:}

Pure Tone Audiometry

Speech Audiometry

Electrocochleography

Caloric Test

Glycerol Test

\section{Clinical Features:}

Vertigo: Spinning movements are experienced. Onset is sudden. Attacks comes in clusters with periods of spontaneous remission.

Nausea, vomiting, nystagmus symptoms of vagal disturbance; Diarrhoea, cold sweats, Bradycardia.

Tullio phenomenon

\section{Hearing loss}

Hearing improves after the attack and may be normal during remission (fluctuating)

Slow and progressive deterioration of hearing.

Distortion of sound; Diplacusis

Intolerance to loud sounds (recruitment) 
Tinnitus: Low pitched, roaring type of sounds are heard in the affected ear.

Sense of fullness or pressure in the ear. Person experiences fullness in the ear during the attack of vertigo or the before the attack of vertigo ${ }^{10}$

Chikitsa: Management in the contemporary science includes medical management with dietary modifications and surgical management.

The management mainly includes low salt diet, Reassurance, avoiding alcohol, avoiding smoking, medical management with diuretics, vestibular sedatives, vasodilators, carbonic anhydrase inhibitors.

Surgical management with chemical labyrinthectomy, vestibular neurectomy, endolymphatic sac surgery. ${ }^{11}$

Chikitsa: The pathology of Meniere's; we understood according to Ayurvedic fundamentals that is the disease manifests mainly as a resultant of Margavrodha Janya or Dhatu Kshaya Janya. Hence our aim should be targeted towards the Samprapti Vighatana.

In Margavarodha Janya Samprapti our line of treatment includes Shodhana which helps to do the Srotoshodhana like Teekshna Nasya, Shodhana Nasya, Snigdha Virechana, etc., but it is utmost important to not to make Vaata Prakopa while doing Shodhana and the medicaments should be of Tridosha Shamaka.

In Dhatukshaya Janya Samprapti we have to adopt the Jeevaniya, Brimhaneeya Chikitsa, Dhatu Bala Vardhana Chikitsa which helps in rebuilding the karma of Shravanendriya. The medicines are Jeevaniya Ghrita, Ashwagandhadi Ghrita, Kalyanaka Ghrita.

In our classics Karna Rogas are explained in detail along with Chikitsa.

Here in Meniere's disease we can adopt the Chikitsa with Amapachana, Agnideepana, Vatanulomana, Balyakara, Rasayana line of treatment. In this disease Kapha Sthanagata Vata Pradhana Pitta Anubandhi and Rajo Guna vitiation. Hence the line of treatment should be of Tridosha hara and Shodhana Chikitsa. The treatment should be planned accordingly starting from Deepana Chikitsa with Shunthi Churna, Shaddharana Vati, based on the patient condition. Followed by Snigdha Virechana ${ }^{12}$ with Gandhrvahastadi Taila or Snehapana with Kalyanaka Ghrita, Sukumara
Ghrita followed by Virechana with Trivrut Leha according to the patient condition. Nasya karma ${ }^{13}$ being the gold standard treatment modality in Urdhwa Jatrugata Vikaras holds good in the management of Meniere's also. In Margavarana Janya Shodhana Nasya is advised with Ushna Veerya, Teekshna Guna and Shodhana, Shothahara medicines like Bhringaraja Svarasa, Gudanagara, Kalyanaka Ghrita, Gandha Tailam, Laxmivilasa Taila. After Shodhana Nasya Shamana Nasya with Brimhana properties can be advised with Dhanvantaram Taila, Ksheerabala 101. After Shodhana Nasya Karma we can employ Karna poorana $^{13}$ which is a Bahya Snehana Swedana selected according to the patient condition

For Karna poorana ${ }^{14}$ we can take Tailas like Bilva Taila, Kshara Taila, Dashamoola Taila, Hingvadi Taila, Apamarga Kshara Taila, Deepika Taila

Some important Aushadha Yogas are Sarivadi Vati this preparation contains Tridoshahara dravyas, Ushna Teekshna, Shothagna, Rasayana effect; Sarivadi Vati stimulates vestibulocochlear function hence helps in the Meniere's disease. Kushmanda Avaleha, Abhraka Bhasma are advised. Along with all these treatment modalities it is very important to give Satwavajaya chikitsa also as the disease progresses patient experiences agitation, lack of confidence, inability in decision making, depression. To make the patient comfortable and for better recovery Satwavajaya Chikitsa is helpful which includes counselling, Autosuggestion, Pranayama like Bhramari.

\section{DISCUSSION}

Acharya Charaka quotes that it is not necessary to name the disease; but it is important to know the Dosha Dhatu Sammurchana by knowing that one can treat any disease.

Meniere's disease is a chronic entity; we can consider the cluster of Karna nada,

Karna Kshweda, Badhirya and Bhrama which are explained in Ayurveda.

By studying we get to know that in meniere's disease we see the involvement of Vata Pradhana Tridoshas and in later stage of the disease involvement Mano Gunas. 
As it is a chronic disease, we encounter the Dhatu Kshaya; and the prevalence is more in middle age to old age group which may facilitate the Vayo Sahaja Karma Kshaya of Indriya.

The major contributing factor for Meniere's disease is modern lifestyle with improper eating and sleeping habits and stressful lifestyle.

So, the management starts with correction in daily routine, Satwavajaya Chikitsa along with Amapachana, Agnideepana, Snigdha Virechana, Vaatanulomana, Nasya Karma, Karnapoorana, Shiropichu. Sadyo Virechana with Gandhrva Hastadi Taila is beneficial; Virechana does the Doshanirharana and mitigates Kleda hence helps in the accumulated endolymph. After Shodhana; Shamana Snehapana with Ashwagandha Ghrita can be encouraged in the conditions where Vata is more dominant. The drugs should be possessed qualities like Madhura Vipaka, Brihamana, Tridoshahara. Ghritapana in Karnarogas acts as Rasayana.

In Meniere's syndrome Koshtha Shuddhi followed by Deepana Pachana Chikitsa is to be followed as because Meniere's syndrome occurs secondary to systemic illness or Endocrinal Disorders like hypothyroidism

Acharyas have mentioned as 'Nasa Hi Shiraso Dhvaram ' nasal route is having direct entry to CNS and nasal route is connected to middle ear by Eustachian tube; keeping these treatment principles in mind Nasya karma is selected as a line of treatment in Meniere's disease. Vatahara Chikitsa, Bhramahara Chikitsa, Samanya Karna Roga Chikitsa should be adopted. The medicaments should be Vata and Kapha hara like, Kalyanaka Ghrita, Bhringaraja Taila etc these Taila or Ghritas reduces the Chala Guna of Vata and also stimulates the cochlear duct, utricle saccule and semi-circular canals for the normal production and absorption of endolymph.

Karnapoorana does Shamana of Vaata Dosha and helps to restore the normal karma of Karnendriya. For Karna Poorana Tailas should be Tridosha Shamaka like Bilva Taila, Deepika Taila. In the treatment course of Karnapoorana it is important to inspect the ear thoroughly each day. In tympanic membrane perforation,
Karnapaka condition any inflammatory changes in external auditory canal Karnapoorana is contraindicated. In Meniere's Disease, patients are in the state of psychological distress, agitation, lack of confidence, social anxiety. In such circumstances Satwavajaya Chikitsa plays a major role in comforting the patient. So, depending on the patient by analysing the condition one can plan the treatment.

\section{CONCLUSION}

Meniere's disease is one among chronic disease, which is very difficult to diagnose. Meniere's disease is considered as a cluster of Karna nada, Karna Kshweda, Badhirya, Bhrama. It is Vata pradhana tridoshaja vyadhi with Rajo Guna vitiation; the disease occurs because of the Margavarodha and Dhatu Kshaya. Hence by adopting the Agnideepana, Srotoshodhana and Vatahara, Brimhaneeya Chikitsa we can manage the condition. After Shodhana Chikitsa Rasayana drugs are advised which helps in degenerative condition of vestibulocochlear nerve.

By diagnosing at early period and adopting the proper Chikitsa according to the patients condition we can help the patients in reducing the suffering.

\section{REFERENCES}

1. B.S. Tuli; Textbook of EAR NOSE and THROAT Jaypee publication second edition Chapter no. 13-Vertigo and Meniere's Disease. Page no- 114 to 117.

2. P. L. Dhingra; Shruti Dhingra; Diseases of Ear Nose \& Throat, Head and Neck Surgery Elsevier Publication $6^{\text {Th }}$ Edition 2014. Chapter no.15 Meniere's Disease Page no.102-104.

3. P. Hazarika D. R. Nayak R. Balakrishnan; Ear Nose Throat and Head \& Neck Surgery Clinical \& Practical; CBS Publication $3^{\text {rd }}$ Edition; Chapter no.19, Diseases of the Inner Ear. Page no.192,193.

4. Mohan Bansal: Diseases of EAR, NOSE \& THROAT Jaypee Publication, First Edition, Chapter no. 22 Peripheral Vestibular Disorders Page no 242.

5. Baye lisa Introduction to the Mystery of Meniere's Disease 1981 Graduate student Theses Dissertations \& Professional papers 2738 University of Montana

6. Edited by Vd. Trikamji Acharya Sushruta Samhita Shree Dalhanacharya virachitaya Nibandhasangraha. 
Chaukamba Sanskrit Sansthana Varanasi 2019, Uttaratantra Chapter no.20 Karnagata roga vigynaniyam, shloka no-7,8, page no-643.

7. Edited by Vd. Trikamji Acharya Sushruta samhita Shree Dalhanacharya virachitaya Nibandhasangraha. Chaukamba Sanskrit Sansthana Varanasi 2019, Uttaratantra Chapter no.20 Karnagata roga vigynaniyam shloka no-9, page no-644.

8. Edited by Vd. Trikamji Acharya Sushruta samhita Shree Dalhanacharya virachitaya Nibandhasangraha. Chaukamba Sanskrit Sansthana Varanasi 2019, Uttaratantra Chapter no.21 Karna roga pratisheda, shloka no 36-37, page no646.

9. Prof. Yadunandan Upadhyaya Madhava Nidana of Sri Madhavakara, Edited, Hindi Commentary, Reprint Edition Vol 1. Chaukamba Prakashana Varanasi 2012, Chapter no17 Murcha Bhrama Nidra Tandra Sanyasa Nidanam.

10. Lopez-Escamez JA, Cary J, Chung WH, et al. Diagnostic Criteria For Meniere's Disease. J Vestib Res.2015;25(1):1-7. doi:3233/VES150549.

11. P L. Dhingra; Shruti Dhingra; Diseases of Ear Nose \& Throat, Head and Neck Surgery Elsevier Publication $6^{\text {Th }}$ Edition 2014. Chapter no.15 Meniere's Disease

12. Prof. Yadunandan Upadhyaya Madhava Nidana of Sri Madhavakara, Edited, Hindi Commentary, Reprint Edition Vol 1. Chaukamba Prakashana Varanasi 2012, Chapter no17 Murcha Bhrama Nidra Tandra Sanyasa Nidanam.

13. Edited by Vd. Trikamji Acharya Sushruta samhita Shree Dalhanacharya virachitaya Nibandhasangraha. Chaukamba Sanskrit Sansthana Varanasi 2019, Uttaratantra Chapter no.21 Karna roga pratisheda, shloka no 36-37, page no646.

14. Dr. G. Prabhakar Rao, Chakradatta Chikitsa Sangraha of Chakrapani Datta Sanskrit Text with English Translation, Chaukamba Publication Varanasi, First Edition Chapter no 57 Karna Roga Chikitsa, Shloka no29, Page no551.

\section{Source of Support: Nil}

\section{Conflict of Interest: None Declared}

How to cite this URL: Anuradha Biserottil, Prashanth A. S: Step Towards Understanding The Mystery Of Meniere's Disease Through Ayurveda. International Ayurvedic Medical Journal \{online\} 2021 \{cited January, 2021\} Available from: http://www.iamj.in/posts/images/upload/2740_2745.pdf 